\title{
Sensory properties and chemical composition of Sharri cheese from Kosovo
}

\author{
doi: $10.15567 / \mathrm{mljekarstvo.2014.0409}$ \\ Agim Rysha ${ }^{*}$ and Frane Delaš ${ }^{2}$ \\ ${ }^{1}$ GIZ Projects, Rr. Gazmend Zajmi 24, 10000 Prishtina, Kosovo \\ ${ }^{2}$ Department of Biochemical Engineering, Faculty of Food Technology and Biotechnology, \\ University of Zagreb, Pierottijeva 6, 10000 Zagreb, Croatia
}

\begin{abstract}
Food sensory properties, analyses and chemical composition are very important because they provide information about product quality and end-user acceptance or preferences. An assessment of sensory characteristics and chemical composition of mountain sheep and cow's-milk cheese from shepherd's huts and industrial manufacturers in Kosovo was carried out. Consumer-oriented tests using a 9 point hedonic scale were conducted in order to determine Sharri cheese acceptability. Chemical parameters (fat content, fat content of dry matter, acidity, protein, dry matter, mineral and water content and sodium chloride content) of 45-day brine cheese samples were also analyzed. Chemical and sensory assessment demonstrated large property differences. A recommendation stems from the results showing that the standardization of both artisanal and industrial production of Sharri cheese is required.
\end{abstract}

Key words: Sharri cheese, sensory properties, chemical composition

\section{Introduction}

Cheese is considered to be one of the most suitable foods for all age groups and consumers regard it as being a nutritional source of proteins, calcium, fat and other nutrients (Fox et al., 1993; Wilkinson et al., 2001). There are over a thousand varieties of cheese produced throughout the world (Fox and McSweeney, 2004). Sensory properties and chemical composition of foods both provide information about the quality of food as well as end-user preferences for such foods. Cheese quality may be defined as the degree of end-user product acceptability (Peri, 2006), and it depends on many factors such as: raw milk composition, processing parameters, starter cultures, storage conditions etc. (Pappa et al., 2007). Sensory analysis is a method to analyze sensory response to samples using senses such as smell taste etc. (Bourne, 2002; Foegeding and Drake, 2007). From two main methods of sensory analyses such as analytical methods which show differences or specific product attributes, and affective methods that quantify liking and disliking response (Lawless, 1994), the acceptance, preference or consumer testing, can be used to determine the degree of liking or disliking for a product (Stone and Sidel, 1995).

Sharri cheese is an indigenous cheese traditionally produced from unpasteurized sheep's milk. Production huts are improvised and primitive and cheese is mostly produced during the summer months. Some industrial dairy plants in the region have started producing their own Sharri mountain cheese using the same traditional techniques; however, unlike mountain producers, they process and pasteurize cow's milk instead of sheep's milk. In Kosovo, dozens of white cheese varieties are produced; however, the traditional Sharri cheese is popular, and is the most consumed cheese in South-Western Kosovo. Although Sharri cheese has been manufactured 
for a long time, the manufacturing techniques used have been not developed properly and are still to be standardized. Lack of knowledge is clearly seen in many manufacturing aspects such as: non stabile raw milk quality, short ripening period and unsuitable/unhygienic processing conditions especially in mountain huts. Previous investigations of the microbiological quality of this cheese have shown that the raw milk, coagulum and ripened cheese samples failed to comply with EU regulations on process hygiene criteria (Rysha et al., 2014). Currently, manufacturers distribute Sharri cheese to the markets even if the cheese has not ripened fully (maximum 14 days) and is of an uncertain quality. The aim of this study was to determine chemical and sensory characteristics of both: Sharri cheese produced from unpasteurized sheep's milk in shepherd's huts as well as Sharri cow's-milk cheese produced in industrial premises. By investigating the main chemical parameters of the cheese we aimed to determine the quantity of basic nutritive ingredients, while hedonic sensory analyses were used to determine the level of acceptability relating to the sensory properties of this cheese.

To the best of our knowledge, this is the first investigation on chemical and sensory quality of Sharri cheese which is traditionally produced in Kosovo, thus we could not refer to any data or to any previous surveys.

\section{Materials and methods}

Cheese samples were analyzed with respect to chemical and sensory characteristics. Analyses were carried out at final products (45-days in brine cheese).

So far, there are no standardized procedures used for the production of Sharri mountain hard cheese but the cheese-making techniques in different parts of Sharri Mountain vary only slightly.

\section{Manufacture of Sharri cheese}

Sharri cheese is made from fresh sheep's or cow's milk from farms within the Sharri Mountain. The fresh milk is filtered through a mesh lining (no longer than 2 hours after milking). Evening milk is mixed with morning milk if stored no longer than 10 hours and not over $10^{\circ} \mathrm{C}$. Before renneting, milk is heated up to $40{ }^{\circ} \mathrm{C}$. Chymosin rennet $(1: 20000-$
1:50000) which is used for curd forming is added at around $28{ }^{\circ} \mathrm{C}$ and the coagulation period takes between 45 and $60^{\circ}$. Whey is separated through pumping and cloth is used for filtering. After the completion of the whey-off, the curd is acquired into a cheese cloth and hang up for drainage for around 10 hours at $18-20{ }^{\circ} \mathrm{C}$ (pre-maturing). Additionally pressing is possible. As a result, the oval-cylindrical cheese (approximately $8-10 \mathrm{~kg}$ ) matures on wooden boards for $5-12$ days at $18-22{ }^{\circ} \mathrm{C}$ (maturing). Relative humidity is between 70-75\%. After breaking it into chunks by hand, the cheese (in chunks of 100$150 \mathrm{~g}$ ) is held in brine for 45 days. Glass or plastic containers are used as packaging material and sea salt is used for the preparation of the brine. Brine concentration is between $5-10 \%$. Sharri cheese is ready for consumption after 45 days ripening in brine.

\section{Chemical analyses}

Samples for chemical analyses (12 samples) were taken from four manufacturing locations; three shepherd's huts (sheep's cheese) and one industrial plant (cow's cheese), using sterile spoons and bags and transported to the laboratory. Eight chemical parameters were studied at the Zagreb University Faculty of Food Technology and Biotechnology - Food Control Centre in Zagreb. A 100 g cheese sample was analyzed for: water content - g/100 g (drying/105 $\left.{ }^{\circ} \mathrm{C}\right)$ (James, 1999), dry matter content/\% (analyzed), mineral content (ash) - g/100 g (gravimetrically/ $600{ }^{\circ} \mathrm{C}$ ) (AOAC, 2005a), fat content - g/100 g (Soxhlet extraction) (ISO, 1999b), fat content in dry matter/\% (analyzed), protein content - g/100 g (AOAC, 2005a), sodium chloride content - g/100 g (titrimetric method) (AOAC, 2005b), acidity in ${ }^{\circ} \mathrm{SH}$ (titrimetric method) (AOAC, 2005c).

\section{Sensory analyses}

Sharri cheese was tested for acceptability as well as for appearance, color, flavor, taste and texture. Samples collected for sensory testing were divided into two categories: 23 cheese samples were produced from unpasteurized sheep's milk, while 8 cheese samples were made from pasteurized cow's milk. No specific criteria were set for entry of samples except for the requirement for the product to have spent at least 45 days in brine. Sensory evaluation was performed using the preference ranking 
test. The test was performed by 8 non-trained panelists who were not specifically trained for testing, but had elementary background knowledge of sensory analyses. They were 18 years of age or older, consumers of Sharri cheese and neither ill nor allergic to any food. Appearance, color, flavor, taste, texture and general perception preferences were evaluated using a 9-point unstructured hedonic scale ranging from 1 (dislike very much) to 9 (like very much) and panelists were asked to choose the most and least preferred sample based on their overall impressions.

They were familiarized on how hedonic scale operates and used ahead of testing. The testing was also a competition in order to select the most preferred Sharri cheese samples.

\section{Statistics}

Descriptive statistics were used for calculation of means and standard deviations between samples. Analyses of variances (one way Anova) was used for comparison of parameters and level of differences between four manufacturers

\section{Results and discussion}

\section{Chemical composition}

The obtained data of Sharri cheese samples produced using sheep's milk (three manufacturers) and cow's milk (one manufacturer) are presented in Table 1

Table 1. Chemical parameters of Sharri cheese

\begin{tabular}{|c|c|c|c|c|}
\hline $\begin{array}{l}100 \mathrm{~g} \text { of cheese } \\
\text { contains: }\end{array}$ & $\begin{array}{l}\text { Manufacturer Prevalle } \\
\text { (Sheep cheese) }\end{array}$ & $\begin{array}{l}\text { Manufacturer Brod } \\
\text { (Sheep cheese) }\end{array}$ & $\begin{array}{l}\text { Manufacturer Radesa } \\
\text { (Sheep cheese) }\end{array}$ & $\begin{array}{l}\text { Manufacturer Prizren } \\
\text { (cow cheese) }\end{array}$ \\
\hline \multirow{3}{*}{ Water/g } & 36.2 & 34.0 & 36.2 & 33.3 \\
\hline & 36.5 & 34.2 & 36.7 & 33.6 \\
\hline & 36.4 & 33.8 & .6 .1 & 34.1 \\
\hline \multirow{3}{*}{ Solids/g } & 63.8 & 65.7 & 63.6 & 66.7 \\
\hline & 63.5 & 65.8 & 63.6 & 66.4 \\
\hline & 63.6 & 66.3 & 63.9 & 65.9 \\
\hline \multirow{3}{*}{ Minerals/g } & 8.6 & 10.9 & 8.0 & 8.6 \\
\hline & 8.7 & 10.5 & 8.1 & 8.3 \\
\hline & 9.0 & 10.4 & 8.2 & 8.9 \\
\hline \multirow{3}{*}{ Fat/g } & 28.2 & 30.3 & 28.2 & 29.9 \\
\hline & 28.1 & 30.2 & 28.1 & 29.5 \\
\hline & 28.1 & 30.5 & 28.6 & 29.4 \\
\hline \multirow{3}{*}{ Fat in dry matter/\% } & 44.2 & 46.0 & 44.3 & 44.8 \\
\hline & 44.2 & 46.0 & 44.2 & 44.4 \\
\hline & 44.2 & 46.0 & 44.7 & 44.6 \\
\hline \multirow{3}{*}{ Protein/g } & 23.9 & 23.1 & 23.9 & 24.1 \\
\hline & 24.2 & 23.6 & 24.0 & 24.7 \\
\hline & 24.1 & 23.5 & 23.8 & 24.4 \\
\hline \multirow{3}{*}{ Sodium chloride/g } & 6.1 & 9.2 & 5.2 & 5.8 \\
\hline & 5.7 & 7.9 & 5.4 & 6.9 \\
\hline & 6.0 & 8.1 & 5.9 & 6.1 \\
\hline \multirow{3}{*}{ Acidity $/{ }^{\circ} \mathrm{SH}$} & 39.2 & 44.3 & 39.8 & 51.3 \\
\hline & 38.9 & 44.7 & 39.6 & 51.4 \\
\hline & 40.5 & 44.2 & 40.6 & 52.5 \\
\hline
\end{tabular}


Table 2. Comparison of cheese content parameters between four different manufacturers

\begin{tabular}{cccccc}
\hline Manufacturer & Prevalle & Brod & Radesa & Prizren & P-value \\
\hline Sample mean/Standard Deviation & $\bar{X}(\mathrm{SD})$ & $\bar{X}(\mathrm{SD})$ & $\bar{X}(\mathrm{SD})$ & $\bar{X}(\mathrm{SD})$ & (F-statistic) \\
\hline \multirow{2}{*}{ Water $(\mathrm{g} / \mathrm{l00} \mathrm{g})$} & 36.367 & 34.000 & 36.333 & 33.667 & 0.000 \\
& $(0.153)$ & $(0.200)$ & $(0.321)$ & $(0.404)$ & $(77.45)$ \\
\hline \multirow{2}{*}{ Solids $(\mathrm{g} / \mathrm{l00} \mathrm{g})$} & 63.633 & 65.933 & 63.700 & 66.333 & 0.000 \\
& $(0.153)$ & $(0.321)$ & $(0.173)$ & $(0.404)$ & $(77.08)$ \\
\hline \multirow{2}{*}{ Minerals $(\mathrm{g} / \mathrm{l00} \mathrm{g})$} & 8.767 & 10.600 & 8.1000 & 8.6000 & 0.000 \\
Fat $(\mathrm{g} / \mathrm{l00} \mathrm{g})$ & $(0.208)$ & $(0.265)$ & $(0.1000)$ & $(0.300)$ & $(67.19)$ \\
\hline \multirow{2}{*}{ Fat in dry matter $(\mathrm{g} / \mathrm{l00} \mathrm{g})$} & 28.133 & 30.333 & 28.300 & 29.600 & 0.000 \\
& $(0.0577)$ & $(0.153)$ & $(0.265)$ & $(0.265)$ & $(80.29)$ \\
\hline \multirow{2}{*}{ Protein $(\mathrm{g} / \mathrm{l} 00 \mathrm{~g})$} & 44.200 & 46.000 & 44.400 & 44.600 & 0.000 \\
& $(0.000)$ & $(0.000)$ & $(0.153)$ & $(0.200)$ & $(72.73)$ \\
\hline \multirow{2}{*}{ Sodium chloride $(\mathrm{g} / \mathrm{l} 00 \mathrm{~g})$} & 24.067 & 23.400 & 23.900 & 24.400 & 0.003 \\
& $(0.153)$ & $(0.265)$ & $(0.100)$ & $(0.300)$ & $(10.78)$ \\
\hline \multirow{2}{*}{ Acidity $\left({ }^{\circ} \mathrm{SH} / \mathrm{l00} \mathrm{g}\right)$} & 5.933 & 8.400 & 5.500 & 6.267 & 0.000 \\
& $(0.208)$ & $(0.700)$ & $(0.350)$ & $(0.569)$ & $(20.20)$ \\
\hline
\end{tabular}

Results from one way analyses of variance are presented in Table 2. One way Anova is used to compare statistical differences between parameters of cheese samples collected from 4 cheese manufacturers.

The results obtained by in the sample analysis collected from three manufacturers of sheep's-milk cheese in Sharri Mountains showed that ready-toeat Sharri cheese (following 45-days in brine) is, on average, characterised by: $35.6 \%$ of moisture, $64.3 \%$ of total solids, $28.9 \%$ of fat, $44.9 \%$ of fat in dry matter, $23.8 \%$ of proteins and $6.6 \%$ of sodium chloride. The low water content in Sharri cheese puts it into the group of hard cheeses (maximum $39 \%$ moisture) similar to Cheddar and Colby which are internally ripened by bacterial fermentation or Swiss Emental or Gouda which are internally ripened by bacterial fermentation plus $\mathrm{CO}_{2}$ production resulting in holes or "eyes" (Vedamuthu and Washam, 1983). The analytical data (Table 2) indicated that Sharri cheese is a hard cheese according to the classification scheme of Codex Alimentarius (Codex Alimentarius, 2007) based on percentage moisture on a fat-free basis (MFFB) (hard 49-56 \%). The average percentage of fat-in-dry matter (FDM) was $44.9 \%$ and according to Codex Alimentarius (Codex Alimetarius, 2007) classification, this cheese will be classed as medium fat (FDM is less than $45 \%$ ). The content of different ingredients varied based on sampling locations.

The study results presented in Table 2 shows that there were significant differences in all measured parameters. The p-value $(0.000)$ for the content of water in $g$ shows that samples were significantly different between each other. Significant differences were found between manufacturer in Prevalle and two other manufacturers Brod and Prizren. No statistically differences were found between manufacturer in Prevalle and Radesa in terms of water content. As far as total solids are concern, significant differences were identified between manufacturer in Prevalle and manufacturers in Brod and Prizren but no significant differences were found between manufacturers in Radesa nad Prevalle. The p-value in terms of mineral contents showed statistically significant differences between Prevalle and manufacturers in Brod and Radesa and no differences were found between Prizren and Prevalle. 
Annex 1. Boxplots of the assessed chemical parameters of Sharri cheese
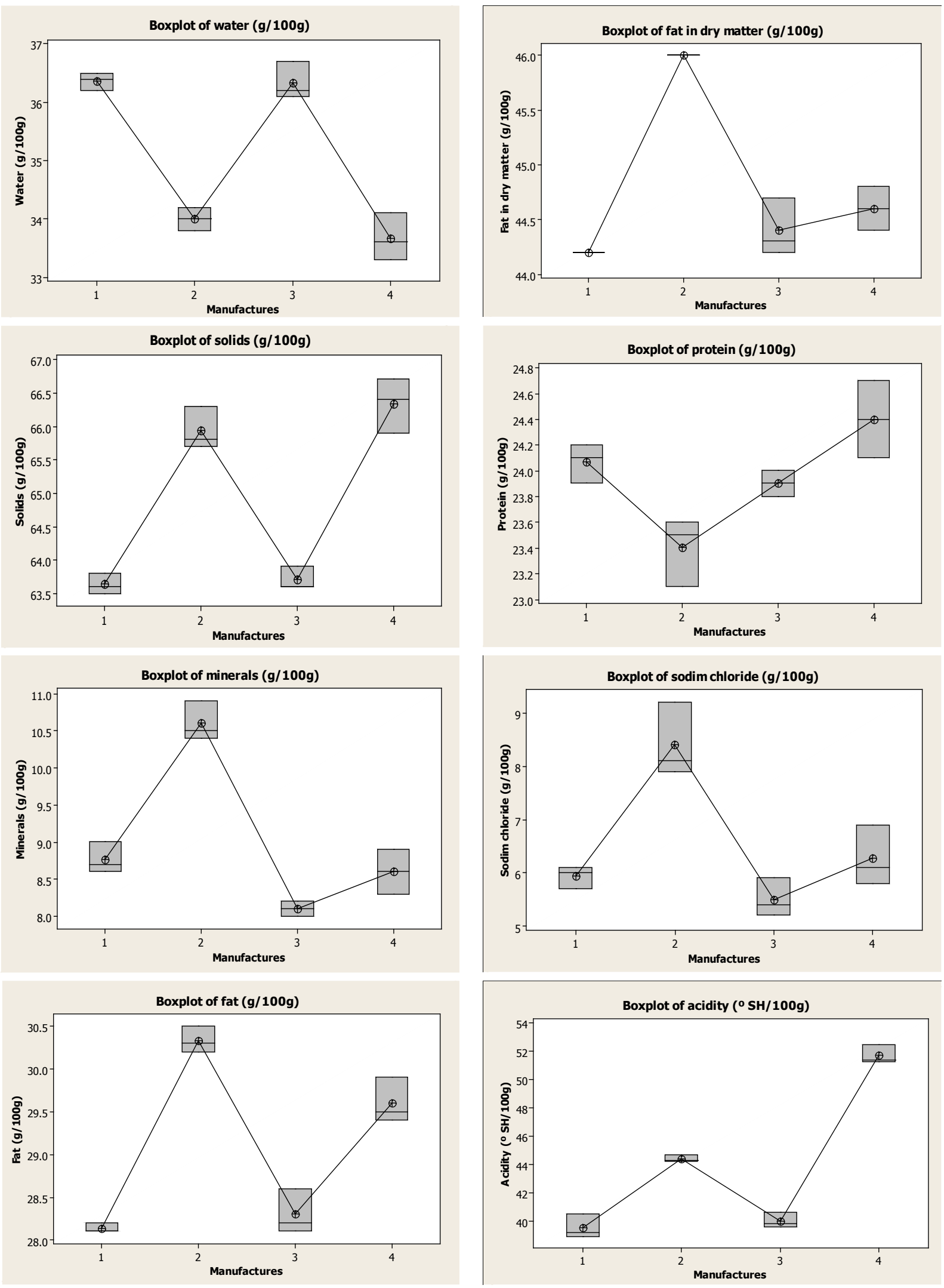
Fat content in cheese produced by manufacturer in Prevalle was significantly different when compared with fat content in cheese produced by manufacturer in Brod and Prizren and no significant differences were found between manufacturer in Radesa and Prevalle in terms of fat content. It seems that shepherd number two did not remove the fat from the milk and the ripening time was a bit longer than in the other two huts. Samples were also significantly different between each other in terms of protein, sodium chloride as well as acidity. Boxplots of the assessed parameters are presented in the Annex 1 .

The causes of these variations can be attributed to the non-standard production and short ripening time. Variation of certain chemical parameters as a consequence of the chemical composition of milk and processing technology was shown in other studies (Hrković et al., 2011). The temperature as well as the humidity during the ripening of the Sharri cheese is not controlled and very often excessive ventilation is not avoided. It seems that the water activity has decreased during the ripening. It is in line with other studies which showed that water activity decrease during ripening and appear to be related to the degree of proteolysis (Hickey et al., 2013). Changes in chemical composition during processing and ripening were not evaluated, but we assume that the dry matter increased and the titratable acidity has decreased as it was shown in numerous other studies (Strnadova et al., 2012). Results of this study showed that samples with low fat content had increased level of moisture and protein while samples with more fat content had lower level of moisture and protein It is in agreement with other studies which showed that the moisture and protein contents increased when the fat content of samples was reduced (Michaelidou et al., 2007; Sabbagh et al., 2010).

There were many changeable content parameters in sheep's and cows cheese. Differences in water and fat content show that applied processing techniques are not standardised. The most stable parameter in both sheep's and cow's cheese was the content of salt which is very high (higher than $6.0 \%$ on average). The high content of sodium chloride was particularly present in sheep's-milk cheese produced by second shepherd. This higher salt concentration (during 45 days) has most probably contributed to the reduction of moisture by favouring free water passage from the curd to the brine and has also contributed for the high salt content of the cheese samples. The salt penetration into the cheese, moisture loss during brining and influence of brine concentration on cheese was shown in other studies too (McMahon et al., 2009; Melilli et al., 2006). In addition, brine concentration may influence on the chemical composition, proteolysis development and rheological characteristics of cheese (Madadlou et al., 2007). A study conducted by Upreti and Metzeger

Table 3. Preference test results for cow's-milk cheese samples

\begin{tabular}{ccccccccc}
\hline & \multicolumn{8}{c}{ Cow's cheese samples with three digit code numbers } \\
\hline Panelists & 643 & 147 & 260 & 452 & 359 & 437 & 251 & 188 \\
\hline 1 & 7 & 6 & 6 & 7 & 6 & 7 & 8 & 8 \\
2 & 6 & 4 & 3 & 3 & 5 & 7 & 7 & 4 \\
3 & 7 & 5 & 6 & 4 & 2 & 4 & 3 & 8 \\
4 & 8 & 6 & 8 & 7 & 6 & 7 & 8 & 9 \\
5 & 8 & 4 & 8 & 7 & 2 & 8 & 7 & 8 \\
6 & 8 & 7 & 7 & 9 & 8 & 9 & 9 & 7 \\
7 & 9 & 5 & 7 & 3 & 3 & 7 & 8 & 8 \\
8 & 7 & 7 & 8 & 6 & 7 & 7 & 7 & 8 \\
Total score & 60 & 44 & 53 & 46 & 39 & 56 & 57 & 60 \\
Average value & 7.50 & 5.50 & 6.62 & 5.75 & 4.87 & 7.00 & 7.12 & 7.50 \\
Maximum score & 72 & 72 & 72 & 72 & 72 & 72 & 72 & 72 \\
$\%$ maximum score & 83.33 & 61.11 & 73.61 & 63.89 & 54.17 & 77.78 & 79.17 & 83.33 \\
\hline
\end{tabular}




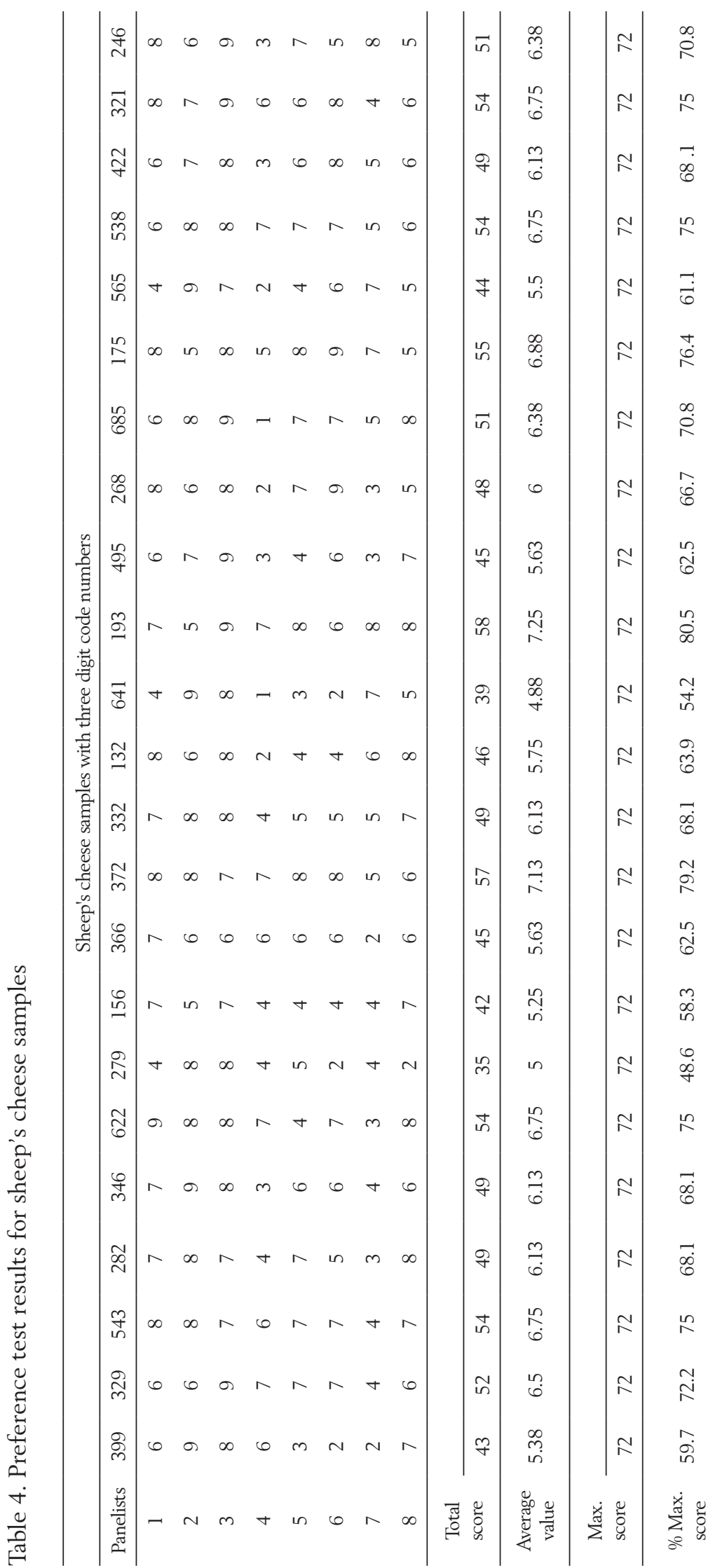

(2006) demonstrated that high salt treatment of Cheddar cheese resulted with lower moisture content compared with those treated with less salt.

\section{Sensory characteristics}

The results of the hedonic rating test for cow's-milk cheese (Table 3) showed that acceptability scores ranged from 39 (54.17\%) up to $60(83.3 \%)$ out of a maximum score of 72 , while the total scores received for sheep's-milk cheese samples (Table 4) ranged from 35 (48.6\%) up to 58 (80.5 $\%)$ out of 72 .

Apart from acceptability scores, panellists described the appearance, color, flavor, taste and texture. Sharri cheese sensory characteristics have not been standardized yet.

The results of this sensory assessment showed large differences in main sensory properties of this cheese. Taste was described as typical or parmesan-like but also as spicy, sweet to sour or salty. Smell was also described as a typical scent of Sharri cheese but at the same time some panelist described as oily or acidic smell. Structure characteristics varied from flat or soft to typical hard consistence. The color also varied from good looking yellow, which is a traditional characteristic of Sharri cheese, but certain samples were described as very white or too dark. The major differences in main sensory properties of Sharri cheese might be due to differences in composition (i.e. differences in fat level and protein to fat ratio), ripening period and ripening conditions (i.e. types of cultures or acid development) etc. Influence of fat and 
protein level as well as ripening period on sensory properties of cheese was shown in other studies (Guinee et al., 2002). The high brine concentration has most probably affected also the sensory properties of Sharri cheese.

\section{Conclusion}

Considering obtained results of the chemical characteristics of Sharri cheese, the cheese can be classified as hard cheese. The differences in the cheese composition were related to the locality of production, indicating that the cheese production is not standardized. The milk source, milk fat level as well as processing conditions such as temperature, $\mathrm{pH}$, ventilation and brine concentration should be optimized and monitored. It seems that the sensory characteristics of this cheese are also affected due to differences in chemical content and ripening period. Very little is known about this autochthonous cheese and there is a need for further investigation of parameters including texture/rheology structure and sensory properties. Products of both natural and under brine ripening processes such as proteolysis and lipolysis should be identified. Currently used starter culture should be studied in order to see their adequacy for Sharri cheese production as well as tolerance towards salty concentrated brine and if needed new starter culture combinations should be developed.

\section{Acknowledgments}

The authors acknowledge the GIZ (previous GTZ) projects in Kosovo for supporting this assessment.

\section{Senzorska svojstva $i$ kemijski sastav Šarskog sira s Kosova}

\section{Sažetak}

Senzorska svojstva i kemijski sastav hrane vrlo su značajni jer pružaju informaciju o kvaliteti proizvoda te o njegovoj prihvatljivosti za krajnjeg korisnika. Provedena je procjena senzorskih karakteristika i kemijskog sastava planinskog sira od ovčjeg i kravljeg mlijeka pastirskih gospodarstava i od industrijskih proizvođača s Kosova. Testiranje potrošača provedeno je hedonističkom ljestvicom s 9 bodova kako bi se utvrdila prihvatliivost Šarskog sira. Također su analizirani kemijski pokazatelji (udio masti, udio masnoća u suhoj tvari, kiselost, proteini, mineralne tvari, te količina vode i natrija) u uzorcima sira u salamuri, pohranjenog 45 dana. Kemijska analiza i senzorska procjena pokazale su velike razlike u svojstvima, što ukazuje na potrebu da se standardizira proizvodnja Šarskog sira, kako u zanatskim tako i u industrijskim uvjetima.

$$
\begin{gathered}
\text { Ključne riječi: Šarski sir, senzorska svojstva, } \\
\text { kemijski sastav }
\end{gathered}
$$

\section{References}

1. AOAC (2005a): Official Method 935.42, $18^{\text {th }}$ edn. Washington, DC: Association of Official Analytical Chemists

2. AOAC (2005b): Official Method 935.43, $18^{\text {th }}$ edn. Washington, DC: Association of Official Analytical Chemists

3. AOAC (2005c): Official Method 920.124, $18^{\text {th }}$ edn. Washington, DC: Association of Official Analytical Chemists

4. Bourne, M. (2002): Food texture and Viscosity: Concept and Measurment. $2^{\text {nd }}$ eds. Academic Press, CA, USA.

5. Codex Alimentarius (2007): Milk and Milk Products, $1^{\text {st }}$ edn., FAO, Rome, Italy.

6. Foegeding, E.A., Drake, M.A. (2007): Sensory and mechanical properties of cheese texture. Journal of Dairy Science 90, 1611-1624. doi: dx.doi.org/10.3168/jds.2006-703

7. Fox, P.F. McSweeney, P.L.H. (2004): Cheese: An overview. In: Fox, P.F., McSweeney, P.L.H., Cogan, T.M., Guinee, T.P. $3^{\text {rd }}$ ed. Vol. 1, Cheese Chemistry Physics and Microbiology, Oxford, Elsevier, pp,1-18.

8. Fox, P.F., Law, J., McSweeney, P.L.H., Wallace, J. (1993): Biochemistry of Cheese Ripening, $2^{\text {nd }}$ ed. Cheese: Chemistry, Physics and Microbiology, Fox, P.F. (Ed). Chapman and Hall, London, UK 1, 389-438.

9. Guinee, T.P., Feeney, E.P., Auty, M.A.E., Fox, P.F. (2002): Effect of $\mathrm{pH}$ calcium concentration on some textural and functional properties of mozzarella cheese. Journal of Dairy Science and Technology 19, 151-162.

10. Hickey, D.K., Guinee, T.P., Hou, J., Wilkinson, M.G. (2013): Effects of variation in cheese composition and maturation on water activity in Cheddar cheese during ripening. International Dairy Journal 30 (1), 53-58. doi: dx.doi.org/10.1016/j.idairyj.2012.11.006

11. Hrković, A., Hodžić, A., Sarić, Z., Hamamdžić, M., Vegara, M., Šaljić, E., Juhas-Pašić, E. (2011): Utjecaj kemijskog sastava ovčjeg mlijeka na kemijski sastav Livanjskog i Travničkog sira. Mljekarstvo 61 (2), 175-181. 
12. ISO (1999b): ISO 1871:2009, Food and Feed Products - General Guidelines for the Determination of Nitrogen by the Kjeldahl Method. Geneva, Switzerland: International Organization for Standardization.

13. James, C.S. (1999): Analytical Chemistry of Foods - Oxford, UK: International Chapman \& Hall

14. Lawless, H.T. (1994): Getting results you can trust from sensory evaluation. Cereals Foods World 39 (11), 809814.

15. Madadlou, A., Khosrowshahi, A., Ebrahimzadeh Mousavi, M., Farmani, J. (2007): The influence of brine concentration on chemical composition and texture of Iranian White cheese. Journal of Food Engineering 81, 330-335. doi: dx.doi.org/10.1016/j.jfoodeng.2006.11.010

16. McMahon, D.J., Motawee, M.M., McManus, W.R. (2009): Influence of brine concentration and temperature on composition, microstructure and yield of feta cheese. Journal of Dairy Science 92, 4169-4179. doi: dx.doi.org/10.3168/jds.2009-2183

17. Melilli, C., Barbano, D.M., Caccamo, M., Tuminello, L., Carpino, S. Licitra, G. (2006): Interaction of brine concentration, brine temperature and presalting on salt penetration in Ragusano cheese. Jornal of Dairy Science. 89,1420-1438. doi: dx.doi.org/10.3168/jds.S0022-0302(06)72211-1

18. Michaelidou, A., Katsiari, M.C.C., Voutsinas, L.P., Polychroniadou, A., Alichanidis, E. (2007): Effect of multiple-species starters on peptide profile and free amino acids in low-fat Kefalogravieratype cheese. Food Chemistry., 104: 800-8007. doi: dx.doi.org/10.1016/j.foodchem.2006.12.041

19. Pappa, E.C., Kandarakis, I., Mallatou, H. (2007): Effect of different types of milks and cultures on the rheological characteristics of "Telemea" cheese, Journal of Food Engineering 79, 143-149. doi: dx.doi.org/10.1016/j.jfoodeng.2006.01.038
20. Peri, C. (2006): The universe of food quality. Food Quality and Preference 17, 3-8. doi: dx.doi.org/10.1016/j.foodqual.2005.03.002

21. Rysha, A., Markov, K., Frece, J., Čvek, D. Delaš, F. (2014): A survey of the microbiological quality of Sharri, a hard mountain cheese from Kosovo. International Journal of Dairy Technology 67 (2), 277-282. doi: dx.doi.org/10.1111/1471-0307.12080

22. Sabbagh, N., Gheisari, H.R., Aminlari, M. (2010): Monitoring the Chemical and Microbiological Changes During Ripening of Iranian Probiotic Low- Fat White Cheese. American Journal of Animal and Veteterinary Sciences 5 (4), 249-257. doi: dx.doi.org/10.3844/ajavsp.2010.249.257

23. Stone, H., Sidel, J.L. (1995): Strategic applications for sensory evaluation in a global market, Food Technology 49 (2), 85-89.

24. Strnadová, D., Konečná, H., Jůzl, M. (2012): Evaluation of quality measurement of Olomoucké tvorůžky) during ripening. Acta Universitatis Agriculturae et Silviculturae Mendelianae Brunensis LX 5, 205- 210. doi: dx.doi.org/10.11118/actaun201260050205

25. Upreti, P., Metzger, L.E. (2006): Influence of Calcium and phosphorus, lactose, and salt-to-moisture ration on Cheddar cheese quality: manufacture and composition. Journal of Dairy Science 89, 420-428. doi: dx.doi.org/10.3168/jds.S0022-0302(06)72106-3

26. Vedamuthu, E.R., Washam, C.J. (1983): Cheese. In Biotechnology Food and Feed Production with Microorganisms, G.Reed, ed., Verlag Chemie, Deerfield Beach, FL.

27. Wilkinson, M.G., Meehan, H., Stanton, C., Cowan, C. (2001): Marketing cheese with a nutrient content. IDF Bulletin, Brussels. International Dairy Federation 363, 39-45. 